\section{Nature Observations From Kamsack}

By Jacob H. Jmaeff, age 13, Kamsack, Sask.

Double-decker Nest - The second Yellow Warbler nest I ever discovered gave me a great thrill. This nest was a double-decker. This happens, I understand, when a Cowbird lays an egg in a Yellow Warbler's nest.

Our class discovered the nest last October while on a nature hike. This nest was on the nonth edge of a small bush which had a smiall slough to the south. The nest was beside a stubble field. The warbler's nest was about four feet off the ground situated in a fine rose bush. Around this wild rose bush were wild raspberries, various weeds, various undergrowth and a woodicutter's brush pile.

The warbler's nest was built of grasis and hair. Upon examination the bottom layer held one cowbird egg plus one warbler egg. The second layer held nothing, which could indicate a successful brood.

Deer at Madge Lake-Among the tamer animals at Madge Lake are the White-tailed Deer. When going west from Madge Llake one should try the side road which leads past the large aluminum Bible Camp hall. This side road is just a detour and leads to the regular highway. On this road, in the pasit two years, our family has seen about fifty deer. They are in groups of three most of the time, usually two adults and a brown, white-spotted fawn.

Two years ago a yearling deer came to Ministik Beach at Madge Lake and romped with the children there. The deer nudged the youngsters and was splashed upon. After a few minutes it scampered away.

To date I have no more information on this beautiful deer.

The Blue Jay-Upon making various queries about Blue Jays, I have found they were common in our district about twenty years ago. Now Blue Jays are rarely seen.

I saw my first Blue Jay last September in a small aspen poplar bush. It was in a tree as the wind swayed the trees to and fro.

I identified the Blue Jay by three main field marks. The Jay was blue all over, had a blue crest and white wing bars.
I watched for the Blue Jay for many days but never saw it aigain.

Northern Pike-Last August, while trolling in Laura Lake, Manitolba, Dad said he had a fish. We stopped the outboard motor and Dad began to reel in. Then out of the green depth emerged four Northern Pike. One was on the hook and the others followed. All were about the same size, fourteen inches. As soon as they saw the boat the three hurried away. This does not happen often and I suppose they all wanted the bait.

Dad told me then of how he caught two fish on one hook. He was fishing in the Assiniboine River when he felt a tug. Upon reeling in he saw a small pike on his hook with an enormous pike biting its mid-section. When trying to land them Dad said they broke off and siwam away. As far as he could see they did not fight again.

A Frog's Fate-One hot Augusit day, while fixing fences, Dad heard a strange squeaking sound. Upon investigation he found a Garter Snake trying to consume a frog. The frog was about four inches long and the snake about twenty-four inches long. The snake was trying to eat the frog head first, but was having a difficult time. All the time the frog was squeaking. Dad quickly pinned down the snake, and to his amazement the frog pcpped out, unharmed. The snake struggled and glided away. The frog then hopped quietly away.

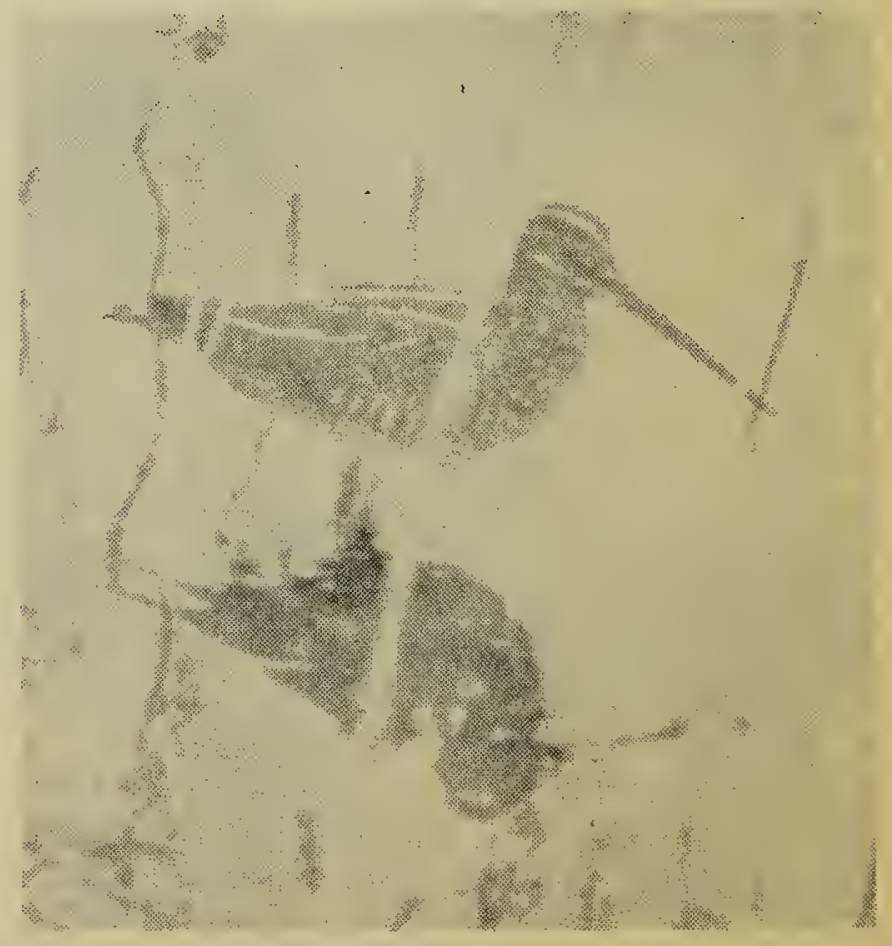

Photo by Glen Fox

CCMMON SNIPE taken at about eight feet without a telephoto lens, Kindersley, August 19, 1958 